PENGARUH NET PROFIT MARGIN RETURN ON ASSET DAN RETURN ON EQUITY TERHADAP HARGA SAHAM

\title{
THE EFFECT OF NET PROFIT MARGIN RETURN ON ASSETS AND RETURN ON EQUITY ON SHARE PRICES
}

\author{
Anugrah Harika Putra ${ }^{1}$, Nanu Hasanuh ${ }^{2}$ \\ Universitas Singaperbangsa Karawang ${ }^{1,2}$ \\ nanu.hasanuh@,fe.unsika.ac.id ${ }^{2}$
}

\begin{abstract}
This study aims to determine the effect of Net Proft Margin, Return On Assets, and Return On Equity Against the Stock Price of Companies in the Financial Services Subsector Listed on the Indonesia Stock Exchange in 2015-2018. This research has occurred a phenomenon and identification of a problem that is quite interesting. The data source used from this research is only secondary data. The selection of samples is based on the criteria and subsector companies of 17 financial institutions and samples taken by 8 companies using the purposive sampling method in the financial institutions subsector companies. This study uses the data analysis methods of classical assumptions and hypothesis testing. The results showed that partially Net Profit Margin and Return On Assets have a significant effect on Stock Prices and partially showed Return On Equity had no significant effect on Stock Prices. Simultaneously, Net Profit Margin, Return On Asset, and Return On Equity have a significant effect on stock price.
\end{abstract}

Keywords : NPM, ROA, ROE, Stock Price

\begin{abstract}
ABSTRAK
Penelitian ini bertujuan untuk mengetahui pengaruh Net Proft Margin, Return On Asset, dan Return On Equity Terhadap Harga Saham Perusahaan subsektor Lembaga Pembiayaan Yang Terdaftar di Bursa Efek Indonesia Tahun 2015-2018. Penelitian ini telah terjadi fenomena dan identifikasi masalah yang cukup menarik. Sumber data yang dimanfaatkan dari penelitian ini hanya data sekunder. Pemilihan sampel berdasarkan kriteria dan perusahaan subsektor lembaga pembiayaan 17 perusahaan dan sampel yang di ambil 8 perusahaan dengan metode Purposive Sampling pada perusahaan subsektor lembaga pembiayaan.. Penelitian ini menggunakan metode analisis data uji asumsi klasik dan uji hipotesis. Hasil penelitian menunjukkan secara parsial Net Profit Margin dan Return On Asset berpengaruh signifikan terhadap Harga Saham dan menunjukkan secara parsial Return On Equity tidak berpengaruh signifikan terhadap Harga Saham. Secara simultan Net Profit Margin, Return On Asset, dan Return On Equity berpengaruh signifikan terhadap Harga Saham.
\end{abstract}

Kata Kunci : NPM, ROA, ROE, Harga Saham 


\section{PENDAHULUAN}

Akhir-akhir ini perkembangan era globalisasi dunia berkembang sangat pesat baik itu mengenai terkait saham yang marak berlomba-lomba mencari keuntungan dengan investasi melalui perusahaan yang sudah terdaftar nama baiknya, menjadi "Go Public" dikalangan pengusaha atau investor menengah keatas tentu giat melakukan sebuah penanaman modal selaku pemilik. Lalu saham banyak diminati dari kalangan orang yang berada sehingga investor akan mencari sebuah perusahaan yang menjamin sang investor menghindari dari sebuah resiko berpengaruh saham yang selalu mengalami penurunan, saham biasanya, sangat retan dipengaruhi oleh beberapa faktor di antara ekonomi, sosial, politik, hubungan internasional melalui perniagaan atau perdagangan dunia melalui kebijakan baru atau peraturan baru yang berlaku setiap negara tertentu,kinerja perusahaan kondisi keuangan stabil atau tidak goyah.

Saham juga sudah banyak peminat pada sekuritas perusahaan "Go Public" dan memberikan pada pengguna informasi tentang kinerja keuangan bersinergi memperoleh laba atau rugi,pengguna informasi atau investor tentu bisa meramalkan sebuah kondisi keuangan perusahaan yang akan datang sebagai acuan bisa mengetahui yang akan terjadi pada perusahaan tersebut memberikan prospek atau timbal balik. Menurut (Martalena \& Malinda, 2016), pasar kapital mempunyai peran signifikan dengan menunjang perekonomian atau pertumbuhan ekonomi suatu negara tertentu. Market Capital dapat dimanfaat sebagai mobilisasi dana yang disalurkan dari investor baik dalam negeri maupun luar negeri.

Berdasarkan hasil persentase Perusahaan Subsektor Lembaga
Pembiayaan di tahun 2016 indeks harga saham terjadi fluktuaktif yaitu sebesar 27 dan menempati angka yaitu sebesar 277. di tahun 2016 Net Profit Margin terjadi fluktuaktif yaitu sebesar $0.03 \%$ dan menempati angka yaitu sebesar $15.45 \%$.

Net profit margin perusahaan subsektor lembaga pembiayaan rata-rata mengalami fluktuaktif. Sedangkan Return on assets perusahaan subsektor lembaga pembiayaan rata-rata mengalami kenaikan. Return on equity perusahaan subsektor lembaga pembiayaan rata-rata mengalami kenaikan. Harga saham perusahaan subsektor lembaga pembiayaan rata-rata mengalami fluktuaktif.

Tujuan untuk mengetahui rasio profitabilitas terhadap perusahaan subsektor lembaga pembiayaan mengenai tentang keuntungan yang di dapat kepada pengguna informasi menanamkan modal terkait perusahaan yang bergerak dibidang pembiayaan memprediksi keuntungan yang dihasilkan cukup membuat pengguna informasi tentang kinerja keuangan perusahaan.kondusif atau membaik.

Menurut (Kasmir, 2017) Net Profit Margin adalah sebuah profit yang rasio antara keuntungan setelah bunga dan pajak atau biaya-biaya dibandingkan antara penjualan membandingkan dengan biaya-biaya ini menggambarkan pendapatan bersih perseroan atas penjualan atau atas emiten.

Menurut Kasmir (2017) Return On Asset adalah menunjukkan dan menggambarkan hasil (Return) atas total harta dimanfaatkan atau dikelolakan dalam perusahaan atau emiten. Menurut Kasmir (2017) Return On Equity merupakan menunjukkan dan menggambarkan hasil (Return) dana pemilik maupun pendanaan kapital pemilik adalah mengukur 
membandingkan ini untuk profit bersih setelah pajak dengan dana pemilik. Menurut Darmadji \& Fakhrudin, (2016) Nilai saham adalah nilai sedang berlangsung di bursa efek pada waktu tertentu atau yang sedang terjadi di Market Capital.

\section{METODE PENELITIAN}

Dari penelitian ini metode menggunakan kuantitatif pendekatan deskriptif dan verifikatif. Dari penelitian ini pendekatan deskriptif digunakan untuk menjawab pengaruh Net Profit Margin (NPM), Return On Assets (ROA), dan Return On Equity (ROE) terhadap Harga Saham.Sedangkan pendekatan verifikatif pada dasarnya ingin menguji kebenaran dari hipotesis yang dilaksanakan melalui pemgumpulan data. Pendekatan verifikatif bertujuan untuk menjawab pengaruh Net Profit Margin (NPM), Return On Assets (ROA), dan Return On Equity (ROE) terhadap Harga Saham subsektor Lembaga Pembiayaan periode tahun 2015-2018.

\section{Definisi Operasional}

Penelitian ini menggunakan definisi operasional rasio profitabilitas adapun variable bebas dan variable terikat berikut penjelasannya :

\section{Net Profit Margin}

Net Profit Margin merupakan pendapatan diperoleh hasil operasi perusahaan dengan perbandingan antara profit bersih sesudah pajak dan pendapatan memberikan suatu keuntungan sebagai nilai kinerja untuk penilaian keuntungan yang diperoleh layak

$\mathrm{NPM}=\frac{\text { Laba Setelah Pajak }}{\text { Penjualan Bersih }}$

\section{Return On Asset}

Return On Assets yaitu dengan perbandingan nilai kinerja emitien total assets (kekayaan) dengan profit bersih sesudah pajak yang dihasilkan dari jumlah assets yang diperoleh perusahaan untuk menunjang produktivitas dan operasi.

$$
\text { ROA }=\frac{\text { Laba Setelah Pajak }}{\text { Total Asset }}
$$

\section{Return On Equity}

Return On Equity merupakan mengukur nilai kinerja emiten dalam modal sendiri dengan laba bersih untuk menjalankan penyaluran dana untuk menjalankan kegiatan atau aktivitas kinerja atau produktivitas perusahaan.

$$
\text { ROE }=\frac{\text { Laba Setelah Pajak }}{\text { Total Equity }}
$$

\section{Harga Saham}

Harga saham yaitu dari indeks harga saham yang sedang fluktuaktif dalam pasar modal sehingga bisa diliat harga pembukaan dan harga penutupan saat pembeli di pasar kapital saham dalam bentuk gambar dan grafik yang menunjukkan angka naik dan turun menentukan harga saham.

\section{Sampel}

Metode pemilihan sampel yang diambil dengan penelitian ini adalah metode Teknik Purposive Sampling, dengan teknik penentuan sampel dengan mempertimbangkan tertentu. Yaitu faktor waktu, jumlah, Harga, persentase, hasil, dan yang terdaftar. Dengan teknik ini, peneliti dapat menentukan dan memilih sampel berdasarkan tujuan tertentu, tetap memenuhi syarat-syarat yang berlaku. Adapun kriteria pemilihan sampel dalam penelitian ini adalah (1) jumlah perusahaan subsektor lembaga 
pembiayaan tahun 2015-2018 tercatat di bursa efek indoensia. (2) emiten mempublikasi dokumen laporan keuangan pada tahun 2015-2018. (3) perusahaan mermiliki kelengkapan dokumen-dokumen kineja perusahaan dari penelitian ini Net Profit Margin, Return On Asset, Return On Equity dan Harga Saham. Berdasarkan dari jumlah populasi perusahaan subsektor lembaga pembiayaan 17 perusahaan dan sampel yang di ambil 8 perusahaan dengan metode Purposive Sampling pada perusahaan subsektor lembaga pembiayaan.

\section{Teknik Analisa Data}

Penelitian ini menggunakan analisis regresi linear berganda dengan pengujian hipotesis uji $\mathrm{F}$ dan $\mathrm{T}$.

\section{HASIL DAN PEMBAHASAN Hasil Uji Hipotesis}

Tabel 1. Hasil Uji F

\begin{tabular}{llrr}
\hline \multirow{2}{*}{1} & & & \\
Model & & $\mathrm{t}$ & \multicolumn{1}{c}{ Sig. } \\
\hline & (Constant) & 4.008 & .000 \\
\cline { 2 - 4 } & NPM & -2.984 & .006 \\
\cline { 2 - 4 } & ROA & 4.187 & .000 \\
\cline { 2 - 4 } & ROE & -.225 & .824 \\
\hline
\end{tabular}

Sumber : Data Olahan SPSS (2021)

Tabel 2. Hasil Uji T

\begin{tabular}{llcr} 
Model & & F & Sig. \\
\hline 1 & Regression & 11.507 & $.000^{\mathrm{b}}$ \\
\cline { 2 - 4 } & Residual & & \\
\cline { 2 - 3 } & Total & & \\
\hline
\end{tabular}

Sumber : Data Olahan SPSS (2021)

Net Profit Margin dengan nilai signifikan senilai $0,006>0,05$, bahwa secara parsial Net Profit Margin berpengaruh signifikan terhadap Harga Saham. Besar Thitung senilai -2,984 dan diperoleh angka Ttabel yaitu senilai 2,048, sehingga Thitung $<$ Ttabel bahwa Net Profit Margin berpengaruh signifikan terhadap Harga Saham dan
Net Profit Margin memiliki hubungan negatif terhadap Harga Saham.

Return On Asset dengan nilai signifikan senilai $0,000>0,05$ bahwa secara parsial Return On Asset berpengaruh signifikan terhadap Harga Saham. Besar Thitung senilai 4,187 dan diperoleh angka Ttabel yaitu sebesar 2,048, sehingga Thitung $<$ Ttabel maka Return On Asset berpengaruh signifikan terhadap Harga Saham dan Return On Asset memiliki hubungan positif terhadap Harga Saham.

Return On Equity dengan nilai signifikan senilai $0,824<0,05$, bahwa secara parsial Return On Equty tidak berpengaruh signifikan terhadap Harga Saham. Nilai Thitung sebesar $-0,225$ dan diperoleh angka Ttabel yaitu sebesar 2,048, sehingga Thitung < Ttabel maka Return On Asset tidak berpengaruh signifikan terhadap Harga Saham dan Return On Equity memiliki hubungan negatif terhadap Harga Saham.

Diperoleh variabel Net Profit Margin, Return On Asset, dan Return On Equity. Diketahui memiliki angka signifikan senilai $0.000<0.05$ diperoleh Fhitung sebesar 11.507 dan diperoleh angka Ftabel 2,93 sehingga dapat dinyatakan bahwa Fhitung $>$ Ftabel yang berarti sebesar 2.93, maka terdapat pengaruh Net Profit Margin, Return On Asset, dan Return On Equity secara Bersama-sama berpengaruh signifikan terhadap Harga Saham. diketahui pengaruh dari ketiga variabel independent Net Profit Margin, Return On Asset dan Return On Equity terhadap Harga Saham senilai 0,504 atau 50,4\% variabel Harga Saham dapat diterangkan dengan variabel independen dalam penelitian Net Profit Margin (NPM), Return On Asset (ROA), dan Return On Equity (ROE) namun sisanya senilai 49,6\% dijelaskan dengan masalah-masalah lain diluar variabel 
independent dalam penelitian ini atau tidak masuk dalam model regresi. Hal ini mengindikasikan ada masalah lain yang mempengaruhi variabel dependen pada hasil penelitian ini.

\section{Pengaruh Net Profit Margin terhadap Harga Saham}

Menurut Kasmir, (2017). Net

Profit Margin adalah sebuah keuntungan dengan membandingkan antara laba setelah bunga dan pajak dibandingkan dengan penjualan rasio ini menunjukkan pendapatan bersih perusahaan atas penjualan atau atas emiten. Menurut Darmadji \& Fakhrudin, (2016) Harga saham adalah harga sedang yang terjadi di bursa pada waktu tertentu atau yang sedang terjadi di pasar modal.

$$
\text { Hasil Penelitian ini }
$$
menunjukkan bahwa Net Profit Margin, terdapat berpengaruh signifikan terhadap Harga Saham. penanam kapital tidak memperhatikan kemampuan kinerja emiten dalam memperoleh penjualan bersih atau pendapatan dengan tidak dikuti meningkatnya laba bersih namun meningkatnya penjualan yang dipengaruhi oleh beban dan biaya yang menghasilkan laba bersih setelah pajak.

Didukung oleh penelitian (Fariantin, 2019) Net Profit Margin merupakan profit yang diperoleh dari membandingkan antara laba setelah bunga dan pajak dengan penjualan, sehingga investor perlu mengetahui berapa nilai bersih dari profit yang didapatkan oleh emiten yang nantinya akan dibagi kepada para penanam kapital yang telah menanamkan modalnya di perusahaan, selain itu Net Profit Margin yang tinggi mencerminkan hasil operasi suatu perusahaan yang baik, karena laba bersih yang diperoleh ternyata melebihi nilai penjualan, Dengan demikian para investor harus paham dan jeli dalam menginvestasikan dananya di perusahaan pencari dana.

\section{Pengaruh Return On Asset terhadap Harga Saham}

Menurut (Kasmir, 2017) Return

On Asset merupakan rasio yang menunjukkan hasil (return) atas jumlah aktiva digunakan dalam perusahaan. Return On Asset juga merupakan suatu ukuran tentang efektivitas manajemen dalam mengolah investasinya. Dan Menurut (Darmadji \& Fakhrudin, 2016) Harga saham adalah harga yang terjadi di bursa pada waktu tertentu.

Berdasarkan hasil ini menunjukkan bahwa Return On Asset berpengaruh signifikan terhadap Harga Saham. maka Harga Saham meningkat. menandakan bahwa investor melihat kemampuan perusahaan dari jumlah asset yang dihasilkan dari investasi yang bersinergi menghasilkan laba bersih untuk meningkatkan produktivitas dan operasi dari sumber penyaluran dana atau modal yang menghasilkan jumlah asset perusahaan.

Didukung Penelitian terdahulu (Fariantin, 2019) ROA merupakan perbandingan profitabilitas yang digunakan untuk mengukur kemampuan efektifitas emiten dalam menghasilkan profit yang melihat aset yang dimiliki oleh perusahaan, sehingga para investor dapat mempertimbangkan keputusan berinvestasi dengan melihat dari kondisi besar-kecilnya nilai ROA. Return On Asset berpengaruh signifikan terhadap Harga Saham.

\section{Pengaruh Return On Equity terhadap Harga Saham}

Menurut (Kasmir, 2017) Return

On Equity merupakan menunjukkan dan menggambarkan hasil pengembalian ekuitas atau Return On Equity atau rentabilitas modal sendiri merupakan 
rasio unkuk mengukur laba bersih setelah pajak dengan modal sendiri atau pemilik. dan Menurut (Darmadji \& Fakhrudin, 2016) Harga saham adalah harga yang terjadi di bursa pada waktu tertentu. Namun teori ini bertolak belakang bahwa modal bersumber dari modal sendiri dikarenakan meningkatnya Return On Equity tidak diikuti meningkatnya harga saham atas minat investasi capital gain dan dividen. Berdasarkan hasil ini menunjukkan bahwa Return On Equity tidak berpengaruh signifikan terhadap Harga saham. Return On Equity memiliki pengaruh negatif hal ini dapat diartikan saat Return On Equity tidak meningkatnya Harga Saham tidak dikuti dengan hubungan yang mempengaruhi menandakan faktor internal bahwa investor melihat perbandingan jumlah modal dan minat investasi dalam berjangka dan mempengaruhi, menunjukkan kondisi naik turun di pasar modal dalam bentuk investasi Capital Gain dan dividen. Faktor eksternal dikarenakan tingkat inflasi dan perlambatan pertumbuhan ekonomi nasional karena sesungguhnya saat terjadi inflasi dan perlambatan ekonomi nasional jumlah ekuitas tidak dipengaruhi.

Didukung penelitian terdahulu (Egam, IIat, \& Pangerapan, 2017) Penelitian ini ditemukan Return on Equity tidak memiliki pengaruh terhadap naik turunnya harga saham. Hal ini bisa berlangsung karena membandingkan ini lebih ditekankan pada unsur pengukuran kemampuan keuangan internal perusahaan tanpa adanya unsur eksternal dari perusahaan. Selain itu Return on Equity tidak menggambarkan keadaan yang sesungguhnya saat berlangsungnya tingkat inflasi, karena saat berlangsungnya tingkat inflasi jumlah kapital tidak terpengaruh, sampai tidak bisa dijadikan perbandingan antara tahun lalu.

Pengaruh Net Profit Margin, Return

On Asset dan Return On Equity Secara Simultan Berpengaruh Signifikan terhadap Harga Saham

Dilihat sudut pandang pengguna informasi bahwa setiap Penjualan Bersih, Total Asset dan Total Ekuitas, kinerja perusahaan menjadi bahan pertimbangan investor untuk berinvestasi atau menanamkan modal dalam suatu perusahaan tersebut mengalami peningkatan atau mengalami penurunan dapat dikatakan bahwa Penjualan Bersih, Asset dan Ekuitas secara langsung berdampak naik turun Harga Saham sebagai tolak ukur dan meramalkan atau memprediksi dalam keadaan dan kondisi keuangan perusahaan di masa yang sedang mendatang. Didukung oleh Penelitian terdahulu menurut (Egam, Ilat, \& Pangerapan, 2017) maka dapat disimpulkan bahwa variabel ROA, ROE dan NPM bersama-sama berpengaruh secara signifikan terhadap harga saham. Sedangkan menurut (Amalya, 2018) Artinya dapat disimpulkan bahwa Return On Equity, Return On Asset, dan Net Profit Margin secara simultan berpengaruh terhadap harga saham.

\section{PENUTUP}

\section{Kesimpulan}

1. Net Profit Margin memiliki pengaruh negatif dan Net Profit Margin berpengaruh signifikan terhadap Harga Saham Perusahaan Lembaga pembiayaan yang terdaftar di bursa efek indonesia tahun 20152018.

2. Return On Asset memiliki pengaruh positif dan Return On Asset berpengaruh signifikan terhadap Harga Saham Perusahaan Lembaga 
pembiayaan yang terdaftar di bursa efek indonesia tahun 2015-2018.

3. Return On Equity memiliki tidak pengaruh negatif dan Return On Equity tidak berpengaruh signifikan terhadap Harga Saham Perusahaan Lembaga pembiayaan yang terdaftar di bursa efek indonesia tahun 20152018 .

4. Net Profit Margin, Return On Asset, dan Return On Equity Secara Simultan berpengaruh Signifikan terhadap Harga Saham.

\section{Saran}

1. Emiten Subsektor Lembaga pembiayaan sebaiknya mampu meningkatkan tingkat kemampuan keuangan perusahaan. Net Profit Margin, Return On Asset, Return On Equity dan Harga Saham sebagai penilaian untuk menilai keadaan keuangan emiten di masa yang akan datang sehingga perlu bersinergi dalam segi operasional dan produktivitas perusahaan menghasilkan keuntungan secara maksimal, seperti hal ini bisa memberikan kesempatan pada seluruh penanam kapital bisa menanamkan kapital terhadap emiten.

2. Dari hasil penelitian ini diharapkan bisa bermanfaat pada penanam untuk menilai perusahaan sektor atau subsketor lain dalam melakukan investasi, dengan melihat tingkat laba yang diperoleh dari perusahaan.

\section{DAFTAR PUSTAKA}

Amalya, T., N. (2018). Pengaruh Return On Asset, Return On Equity, Net Profit Margin dan Debt To Equity Ratio terhadap Harga Saham. Jurnal Sekuritas. 1(3): 157-181.

Darmadji, T., \& Fakhrudin, M., H. (2016). Pasar Modal di Indonesia. Edisi 3. Jakarta: Salemba Empat.

Egam, Y., Edsel., Gerald IIat, Ventje., Pangerapan, \& Sonny. (2017). Pengaruh Return On Assets (ROA), Return On Equity (ROE), Net Profit Margin (NPM), dan Earning Per Share (EPS) Terhadap Harga Saham Perusahaan Yang Tergabung Dalam Indeks LQ45 Di Bursa Efek Indonesia Periode Tahun 2013-2015. Jurnal EMBA. 5(1). 105-114.

Fariantin, E., H.,J. (2019). Pengaruh Return On Asset (ROA) dan Net Profit Margin (NPM) terhadap Harga Saham Pada Perusahaan Farmasi Tbk yang Terdaftar di Bursa Efek Indonesia. Journal unmasmataram. 13(1): 136-145.

Kasmir. (2017). Analisis Laporan Keuangan. Jakarta: Raja Grafindo Persada.

Martalena \& Malinda, M. (2016). Pengantar Pasar Modal. Edisi 1. Yogyakarta: Andi. 